\title{
Accelerated aging test in niger seeds ${ }^{1}$
}

\author{
Carla Regina Baptista Gordin²*, Silvana de Paula Quintão Scalon², \\ Tathiana Elisa Masetto ${ }^{2}$
}

\begin{abstract}
Niger is a promising oilseed species for biodiesel production but there is no much information about the physiological potential of its seeds. Thus, the aim was to adapt the methodologies of accelerated aging test on six lots of niger seeds. The test was carried out by traditional and with saturated salt solution $\left(20\right.$ and $\left.40 \mathrm{~g} \mathrm{NaCl} .100 \mathrm{~mL}^{-1}\right)$ methods at 41 and $45^{\circ} \mathrm{C}$ for $24,48,72$ and 96 hours. After the decay period, the seeds were submitted to the germination test, proceeding to an evaluation on the seventh day after sowing, counting the normal seedlings percentage. A completely randomized design with four replications of 50 seeds was used and the means were compared by Tukey's test. The accelerated aging test was correlated with seedling emergence and provided lots classification in at least two levels of vigor. For the accelerated aging test, the method with $20 \mathrm{~g} \mathrm{NaCl} .100 \mathrm{~mL}^{-1}$ at $41{ }^{\circ} \mathrm{C}$ for 24 hours is recommend. The traditional method is not suitable because it provides water content variation between samples above what is tolerable.
\end{abstract}

Index terms: biodiesel, Guizotia abyssinica (L.f.) Cass., oilseed, vigor.

\section{Teste de envelhecimento acelerado em sementes de niger}

\begin{abstract}
RESUMO - O niger é uma espécie oleaginosa de interesse para a produção de biodiesel com poucas informações sobre o potencial fisiológico de suas sementes. Portanto, objetivou-se adequar as metodologias do teste de envelhecimento acelerado para a avaliação do vigor de seis lotes de sementes de niger. Utilizaram-se os métodos tradicional e com solução saturada de sal (20 e $40 \mathrm{~g}$ de NaCl. $\left.100 \mathrm{~mL}^{-1}\right)$, nas temperaturas de 41 e $45^{\circ} \mathrm{C}$ por 24, 48, 72 e 96 horas. Após o período de deterioração, as sementes foram submetidas ao teste de germinação e procedeu-se a avaliação, aos sete dias após a semeadura, contabilizandose a porcentagem de plântulas normais. O delineamento experimental utilizado foi o inteiramente casualizado, com quatro repetições de 50 sementes e as médias comparadas pelo teste de Tukey. $\mathrm{O}$ teste de envelhecimento acelerado correlacionouse com o teste de emergência de plântulas e proporcionou a estratificação dos lotes em pelo menos dois níveis de vigor, recomendando-se o método com $20 \mathrm{~g} \mathrm{NaCl} .100 \mathrm{~mL}^{-1}$ a $41{ }^{\circ} \mathrm{C}$ por 24 horas. O método tradicional não é recomendado por proporcionar variação do teor de água entre as amostras, superior ao tolerável.
\end{abstract}

Termos para indexação: biodiesel, Guizotia abyssinica (L.f.) Cass., oleaginosa, vigor.

\section{Introduction}

Among the species with potential for commercial production of biodiesel, niger (Guizota abyssinica (L.f.) Cass.) is highlighted, characterized by high oil production $(30 \%$ of the weight of the seeds), with a high content of linoleic acid. In tropical Africa, its center of origin, the oil has many uses, especially in food, and in Brazil, it is considered promising for the production of biomass when used as ground cover in autumn/winter (Getinet and Sharma, 1996; Kuo et al., 2007; Carneiro et al., 2008; Sarin et al., 2009; Solomon and Zewdu, 2009). However, although the species has economic potential, there is little information concerning the evaluation of the seeds physiological potential, as production technologies and standards for marketing them are still nonexistent.

In the evaluation of the seeds physiological quality, germination test provides essential information on the best conditions for germination in order to exploit the seeds full potential. However, it does not provide necessary information on the capacity of seeds lots to set up a stand in adverse field conditions (Ventura et al., 2012). Thus, vigor tests may be used to assess the satisfactory stand establishment under different environmental conditions, complementing the information provided by the germination test (Grey et al., 2011).

\footnotetext{
${ }^{1}$ Submitted on 06/01/2015. Accepted for publication on 8/19/2015.

${ }^{2}$ Universidade Federal da Grande Dourados, Caixa Postal 533, 79804-970 - Dourados, MS, Brasil.

*Corresponding author < carlagordin@ufgd.edu.br>
} 
Among the vigor tests, the accelerated aging test involves subjecting the seeds to high temperatures and relative humidities, simulating normal storage conditions, but with an increase in the decay rate (MoncaleanoEscandon et al., 2013).

In order to avoid uneven water absorption among the samples, which may result in a differentiated decay, affecting post-aging results, Jianhua and McDonald (1996) have proposed the replacement of water by saturated salt solutions. With this procedure, there is reduction of the medium relative humidity, ensuring that the effects of decay should be due to temperature and exposure period (Moncaleano-Escandon et al., 2013).

Thus, due to the species economic potential and the need for knowledge about assessment methods of the vigor of its seeds, this study aimed to adapt the methods of traditional accelerated aging tests and with saturated salt solutions to evaluate the niger seeds vigor.

\section{Material and Methods}

The study was conducted at the Seed Technology Laboratory of the Faculty of Agricultural Sciences at University Federal of Grande Dourados (UFGD) in 2013. Six lots of niger seeds were used, one being produced in the 2009/2010 harvest (Lot 1), in the Brazilian municipality of Primavera do Leste, MT, four produced at different times in the 2011/2012 harvest (Lots 2 to 5) on Experimental Farm of the Faculty of Agricultural Sciences at UFGD (FAECA) and the last one also produced at FAECA, in the 2012/2013 harvest (Lot 6). The seeds were kept in paper packaging and stored in a cold and dry room $\left(15{ }^{\circ} \mathrm{C}\right.$ and $\left.45 \% \mathrm{RH}\right)$ until the establishment of the experiments.

The lots were initially assessed for the following tests and determinations: moisture content, performed using the method of the oven at $105 \pm 3{ }^{\circ} \mathrm{C}$ for 24 hours, with four replications, according to Brasil (2009); germination test conducted on Germitest $^{\circledR}$ paper dampened at the equivalent of 2.5 times the dry paper mass, inside "gerbox"-type germination boxes, placed in a B.O.D (Biochemical Oxygen Demand)-type germination chamber regulated at $25{ }^{\circ} \mathrm{C}$ with continuous light (six Philips ${ }^{\circledR}$ "daylight"-type fluorescent lamps of 20 watts and photon irradiance of $32.85 \mu \mathrm{mol} . \mathrm{m}^{-2} \cdot \mathrm{s}^{-1}$ ), using four replications of 50 seeds (Gordin et al., 2012). Evaluations were performed seven days after sowing, recording the germination percentage, taking into account the formation of normal seedlings (developed shoot and root system); germination first count held together with the germination test, counting the number of normal seedlings obtained on the third day after sowing, according to results obtained in preliminary tests; germination speed index, according to Maguire (1962); mean germination time, according to the formula proposed by Edmond and Drapalla (1958); and seedling length and dry matter by randomly choosing ten normal seedlings, measured with a digital caliper and dried in an oven at $65{ }^{\circ} \mathrm{C}$ for 72 hours, followed by weighing on a precision scale.

Seedling emergence under controlled conditions was obtained from seedings in trays filled with dystrophic red latosol, wrapped in a greenhouse coated with Sombrite ${ }^{\circledR}$, with $30 \%$ dimming in the experimental area at FCA/ UFGD. The temperature and average relative humidity in the experiment conduction period were $31{ }^{\circ} \mathrm{C}$ and $58 \%$. The speed index and the mean emergence time were recorded and, at 15 days after planting, the emergence percentage and dry matter length and seedling assessments were held, obtained in the same way as for the germination test; the initial stand was held in conjunction with the field emergence testing, registering the number of seedlings emerged on the third day after sowing, according to results obtained in pretests.

The traditional accelerated aging test was performed for each lot in individual chambers made of wire mesh suspended inside, where an even layer of niger seeds $(1 \mathrm{~g})$ was distributed. Within each individual compartment were added $40 \mathrm{~mL}$ of distilled water, being 100\% relative humidity (Jianhua and McDonald, 1996) and the boxes were placed in the greenhouse at 41 and $45^{\circ} \mathrm{C}$ for $24,48,72$ and 96 hours. After these periods, the seeds were immersed for five minutes in $2 \%$ sodium hypochlorite, washed in distilled water and subjected to the germination test (Gordin et al., 2012), recording the germination percentage at seven days after sowing. The moisture content of the seeds was also determined (Brasil, 2009) before and after the aging period. For the accelerated aging test with a saturated solution, the same methodology as for the traditional test was used, replacing the distilled water by $40 \mathrm{~mL}$ of saturated sodium chloride $(\mathrm{NaCl})$ in the concentrations of 20 and $40 \mathrm{~g} .100 \mathrm{~mL}^{-1}$, corresponding to 76 and $55 \%$ of relative humidity, respectively (Jianhua and McDonald, 1996).

A completely randomized design with four replications of 50 seeds was used. The data were submitted to tests of normality and homogeneity of variance and then to ANOVA and, if significant, the averages were compared by Tukey's test at $5 \%$ probability, by means of the computer program SISVAR $^{\circledR}$ (Ferreira, 2011). Later, the simple Pearson correlation coefficients ( $r$ ) were calculated among the initial characterization and accelerated aging testing and field emergence testing, determining the significance of the $r$ values by the t-test at $5 \%$ probability. 


\section{Results and Discussion}

Lots of niger seeds differed as to seed physiological quality in all traits assessed, highlighting lot 6 as having more vigor than the others, except for the percentage of germination and seedling length held during the emergence test, which was not sensitive in detecting the differences between the lots (Table 1).

By the first count of germination, lots 1, 2 and 4 had intermediate vigor, noting that lots 3 and 5 showed the lowest and 6 the highest vigor compared to the others. By the germination speed index, lot 6 was also considered superior compared to the others, as well as by the mean germination time, which also identified lots 1, 2, 3 and 4 with high vigor compared to lot 5 . The high vigor of lot 6 was also identified by the seedlings length and dry matter (both in the germination and emergence tests), which also found lots 1, 2, 4 and 5 with high vigor compared to the others (Table 1).

Table 1. Seed germination and seedlings emergence of niger (Guizotia abyssinica) seeds from different lots.

\begin{tabular}{|c|c|c|c|c|c|c|c|c|c|c|c|c|}
\hline \multirow{3}{*}{ Lots } & \multicolumn{6}{|c|}{ Germination } & \multicolumn{6}{|c|}{ Emergence } \\
\hline & $\mathrm{G}$ & $\mathrm{FC}$ & \multirow[t]{2}{*}{ GSI } & MGT & $\mathrm{TL}$ & DM & $\mathrm{E}$ & IS & \multirow[t]{2}{*}{ ESI } & MET & TL & DM \\
\hline & \multicolumn{2}{|c|}{$(\%)$} & & days & $\mathrm{mm}$ & g.seedling $^{-1}$ & \multicolumn{2}{|c|}{$(\%)$} & & days & $\mathrm{mm}$ & g.seedling ${ }^{-1}$ \\
\hline 2 & $81 \mathrm{a}$ & $48 \mathrm{bc}$ & $9.25 \mathrm{~b}$ & $1.98 \mathrm{a}$ & $26.4 \mathrm{~b}$ & $0.0033 \mathrm{a}$ & $38 \mathrm{~b}$ & $26 \mathrm{~b}$ & $2.53 \mathrm{bc}$ & $4.13 a b$ & $69.0 \mathrm{a}$ & $0.0037 \mathrm{ab}$ \\
\hline 3 & $85 \mathrm{a}$ & $29 \mathrm{c}$ & $5.15 \mathrm{~b}$ & $2.20 \mathrm{ab}$ & $46.8 \mathrm{~b}$ & $0.0023 \mathrm{~b}$ & $30 \mathrm{~b}$ & $20 \mathrm{~b}$ & $1.48 \mathrm{c}$ & $4.18 \mathrm{ab}$ & $73.1 \mathrm{a}$ & $0.0028 \mathrm{~b}$ \\
\hline 4 & $84 \mathrm{a}$ & $53 \mathrm{bc}$ & $8.46 \mathrm{~b}$ & $2.09 \mathrm{ab}$ & $57.6 \mathrm{ab}$ & $0.0030 \mathrm{a}$ & $44 \mathrm{ab}$ & $27 \mathrm{~b}$ & $3.41 \mathrm{~b}$ & $3.48 \mathrm{a}$ & $65.8 \mathrm{a}$ & $0.0052 \mathrm{a}$ \\
\hline 5 & $84 \mathrm{a}$ & $59 \mathrm{ab}$ & $5.31 \mathrm{~b}$ & $2.61 \mathrm{~b}$ & $48.2 \mathrm{ab}$ & $0.0030 \mathrm{a}$ & $41 \mathrm{ab}$ & $18 \mathrm{~b}$ & $2.44 \mathrm{bc}$ & $5.00 \mathrm{ab}$ & $72.2 \mathrm{a}$ & $0.0044 \mathrm{ab}$ \\
\hline 6 & $91 \mathrm{a}$ & $79 \mathrm{a}$ & $20.67 \mathrm{a}$ & $1.94 \mathrm{a}$ & $79.1 \mathrm{a}$ & $0.0030 \mathrm{a}$ & $71 \mathrm{a}$ & $55 \mathrm{a}$ & $7.35 \mathrm{a}$ & $3.80 \mathrm{ab}$ & $78.2 \mathrm{a}$ & $0.0043 \mathrm{ab}$ \\
\hline C. V. $(\%)$ & 6.1 & 11.3 & 20.5 & 11.8 & 27.2 & 10.3 & 15.2 & 22.6 & 25.3 & 16.8 & 13.4 & 22.0 \\
\hline
\end{tabular}

${ }^{1}$ Means followed by the same letter in the column do not differ among themselves by the Tukey's test at 5\% probability. (G) germination; (FC) germination first count; (GSI) germination speed index; (MGT) mean germination time; (TL) seedlings total length; (DM) seedlings dry matter; (E) emergence; (IS) initial stand; (ESI) emergence speed index; (MET) mean emergence time; (TL) seedlings total length and (DM) seedlings dry matter.

In the seedling emergence test, the seeds of lot 6 showed up with more vigor than in the other lots by the percentage of emergence, initial stand and emergence speed index, and on the last test it was possible to see that lots 1 and 3 had lower emergence speed, being classified as less vigorous compared to lots 2, 4 and 5, of intermediate vigor. Lots 2-6 did not differ as to the mean germination time, with high vigor with respect to lot 1 (Table 1).

Often the germination test is not sensitive enough to detect differences between lots, as observed in this study, although obtained in different growing conditions, for it provides optimal conditions for the expression of the seeds maximum physiological potential. Thus, the need to complement their results by the vigor testing in seed lots with similar germination is confirmed (Bolek, 2010).

All initial characterization tests of the lots were significantly correlated $(p<0.05)$ with seedling emergence, except the evaluation of seedlings length conducted during the germination test (Table 2). There was a negative correlation of seedlings emergence test with seedlings mean germination time and emergence speed index and a positive correlation with other tests; however, the correlations with the seedling length test in a greenhouse and seedlings dry matter conducted in both environments were considered low. Thus, the percentage assessments, speed index, germination first count, emergence speed index and initial stand are indicated for the evaluation of the niger seeds physiological quality, as they estimate the seedlings emergence.

Table 2. Simple Pearson correlation coefficients (r) estimated between germination tests and seedling field emergence, in six lots of niger (Guizotia abyssinica) seeds.

\begin{tabular}{|c|c|c|c|c|c|c|c|c|c|c|c|}
\hline & \multicolumn{6}{|c|}{ Germination } & \multicolumn{5}{|c|}{ Emergence } \\
\hline & $\mathrm{G}$ & $\mathrm{FC}$ & GSI & MGT & $\mathrm{TL}$ & $\mathrm{DM}$ & IS & ESI & MET & TL & DM \\
\hline E & $0.729^{* *}$ & $0.900^{*}$ & $0.949^{* *}$ & $-0.537^{* *}$ & $0.753^{\mathrm{ns}}$ & $0.386^{* *}$ & $0.933^{* *}$ & $0.992^{* *}$ & $-0.465^{* *}$ & $0.647^{* *}$ & $0.408^{* *}$ \\
\hline
\end{tabular}

$(*)$ Significant at $5 \%$ probability by the t-test; $(* *)$ Significant at $1 \%$ probability by the t-test; (ns) nonsignificant at $5 \%$ probability by the t-test; (E) emergence percentage; (G) germination percentage; (FC) germination first count; (GSI) germination speed index; (MGT) mean germination time; (TL) seedlings total length; (DM) seedlings dry matter; (IS) initial stand; (ESI) emergence speed index and (MET) mean emergence time. 
In Tables 3 and 4 it is possible to see the values of the seeds moisture content before and after the period of exposure to high temperatures and concentrations of $\mathrm{NaCl}$. Comparing the traditional and modified procedures, it was observed, in general, that the seed water content was quite high in the traditional method, at both temperatures used.

Table 3. Moisture content of niger (Guizotia abyssinica) seeds before (RH) and after the aging period (AA) at the temperature of $41^{\circ} \mathrm{C}$.

\begin{tabular}{|c|c|c|c|c|c|c|c|c|c|c|c|c|c|}
\hline \multirow{3}{*}{ Lots } & \multirow{3}{*}{$\begin{array}{l}\text { RH } \\
(\%)\end{array}$} & \multirow{2}{*}{\multicolumn{4}{|c|}{ Traditional AA }} & \multicolumn{8}{|c|}{ AA with salt saturation } \\
\hline & & & & & & \multicolumn{4}{|c|}{$20 \mathrm{~g} \mathrm{NaCl}^{2} 100 \mathrm{~mL}^{-1}$} & \multicolumn{4}{|c|}{$40 \mathrm{~g} \mathrm{NaCl} 100 \mathrm{~mL}^{-1}$} \\
\hline & & $24 \mathrm{~h}$ & $48 \mathrm{~h}$ & $72 \mathrm{~h}$ & $96 \mathrm{~h}$ & $24 \mathrm{~h}$ & $48 \mathrm{~h}$ & $72 \mathrm{~h}$ & $96 \mathrm{~h}$ & $24 \mathrm{~h}$ & $48 \mathrm{~h}$ & $72 \mathrm{~h}$ & $96 \mathrm{~h}$ \\
\hline 1 & 9.4 & 42.2 & 46.4 & 59.5 & 59.2 & 13.2 & 13.3 & 13.6 & 10.6 & 8.1 & 9.0 & 8.5 & 8.5 \\
\hline 2 & 8.1 & 42.6 & 48.9 & 54.9 & 50.3 & 14.2 & 13.5 & 14.3 & 11.8 & 9.3 & 10.1 & 9.4 & 10.1 \\
\hline 3 & 10.5 & 45.8 & 46.1 & 47.8 & 46.9 & 15.3 & 13.1 & 13.8 & 11.9 & 10.4 & 10.5 & 9.4 & 9.3 \\
\hline 4 & 9.3 & 44.5 & 52.4 & 55.7 & 59.1 & 15.7 & 13.5 & 14.6 & 12.4 & 9.8 & 9.5 & 10.0 & 9.2 \\
\hline 5 & 8.4 & 46.0 & 54.3 & 50.3 & 40.2 & 15.6 & 11.7 & 13.1 & 12.3 & 9.4 & 8.6 & 8.7 & 8.2 \\
\hline 6 & 8.5 & 48.3 & 46.8 & 46.8 & 42.8 & 13.6 & 12.6 & 12.7 & 10.9 & 9.7 & 9.6 & 9.2 & 8.9 \\
\hline
\end{tabular}

Table 4. Moisture content of niger (Guizotia abyssinica) seeds before (RH) and after the aging period (AA) at the temperature of $45^{\circ} \mathrm{C}$.

\begin{tabular}{|c|c|c|c|c|c|c|c|c|c|c|c|c|c|}
\hline \multirow{3}{*}{ Lots } & \multirow{3}{*}{$\begin{array}{l}\text { RH } \\
(\%) \\
\end{array}$} & \multirow{2}{*}{\multicolumn{4}{|c|}{ Traditional AA }} & \multicolumn{8}{|c|}{ AA with salt saturation } \\
\hline & & & & & & \multicolumn{4}{|c|}{$20 \mathrm{~g} \mathrm{NaCl} 100 \mathrm{~mL}^{-1}$} & \multicolumn{4}{|c|}{$40 \mathrm{~g} \mathrm{NaCl} 100 \mathrm{~mL}^{-1}$} \\
\hline & & $24 \mathrm{~h}$ & $48 \mathrm{~h}$ & $72 \mathrm{~h}$ & $96 \mathrm{~h}$ & $24 \mathrm{~h}$ & $48 \mathrm{~h}$ & $72 \mathrm{~h}$ & $96 \mathrm{~h}$ & $24 \mathrm{~h}$ & $48 \mathrm{~h}$ & $72 \mathrm{~h}$ & $96 \mathrm{~h}$ \\
\hline 1 & 9.4 & 41.4 & 44.4 & 47.2 & 41.0 & 16.5 & 12.0 & 12.5 & 16.5 & 10.2 & 9.0 & 8.9 & 11.4 \\
\hline 2 & 8.1 & 45.2 & 52.0 & 40.2 & 40.4 & 15.9 & 13.4 & 14.5 & 17.5 & 10.6 & 10.2 & 10.1 & 13.0 \\
\hline 3 & 10.5 & 49.9 & 54.8 & 56.7 & 54.4 & 18.3 & 14.0 & 14.5 & 17.6 & 11.2 & 10.2 & 10.1 & 13.4 \\
\hline 4 & 9.3 & 50.8 & 60.1 & 60.1 & 54.5 & 16.5 & 13.5 & 13.7 & 17.1 & 10.9 & 10.1 & 10.2 & 13.5 \\
\hline 5 & 8.4 & 47.2 & 51.6 & 47.3 & 46.5 & 16.0 & 11.8 & 13.4 & 15.5 & 10.2 & 9.0 & 9.0 & 11.5 \\
\hline 6 & 8.5 & 40.8 & 42.2 & 46.3 & 43.3 & 17.1 & 12.2 & 14.0 & 16.5 & 10.7 & 10.2 & 9.6 & 12.8 \\
\hline
\end{tabular}

According to Peng et al. (2011), increasing exposure of the seeds to artificial aging leads to the accumulation of reactive oxygen species causing lipid peroxidation and therefore less integrity and selectivity of the membranes, allowing entry of water more quickly in the cells. However, the use of a saturated salt solution promotes greater control of the aging chamber relative humidity, providing delay of the water absorption by the seeds (Jianhua and McDonald, 1996).

Thus, the seeds tend to reach hygroscopic equilibrium at higher water contents as the relative humidity increases, according to what was verified by Nery et al. (2009) and Braz et al. (2008) in seeds of forage turnip (Raphanus sativus L. var oleiferus Metzg.) and sunflower (Helianthus annus L.), respectively, where lower and more uniform moisture contents were obtained with the use of a saturated salt solution during the aging period, compared to those observed for the seeds aged by the traditional method, providing lower and slower water absorption by the seeds of this species.

The initial moisture content of the seeds did not vary more than two percentage points among samples, as recommended by Marcos-Filho (2005). However, after the aging period, the traditional method provided, at both temperatures, the variation of water content among the samples, exceeding the tolerable (Table 3), and the presence of microorganisms was also seen. According to Marcos-Filho (2005), these factors are undesirable for performing the test because they compromise the results fidelity, as the wetter samples are more sensitive to more intense decay, and microorganisms impair seedling germination and development, causing uncertainty regarding their normality, and hindering the test interpretation.

Importantly, these effects have been detected in a more drastic manner in typically smaller seeds, which is a criterion that fits the niger seeds, which are on average $4.54 \mathrm{~mm}$ long, $1.39 \mathrm{~mm}$ wide and $1.15 \mathrm{~mm}$ thick (Gordin et al., 2012). These seeds absorb water more rapidly, characterizing phase I of the seed hydration three-phase pattern and, after that period, also referred to as phase II, there is little or no water absorption, because the seeds cells can no longer expand, and it is possible to notice, already from this stage, the activation of metabolic processes required for embryo growth and early germination processes (Castro et al., 2004). 
The accelerated aging tests results were significant $(p<0.05)$ in all methods used. In general, tests performed at the temperature of $41{ }^{\circ} \mathrm{C}$ were effective at distinguishing the lots in terms of the physiological quality in three levels of vigor, except in times of 72 hours in the traditional procedure and 96 hours with a saturated solution at a concentration of $20 \mathrm{~g} \mathrm{NaCl} .100 \mathrm{~mL}^{-1}$, which provided a distinction of lots on two vigor levels, as in the seedling emergence test. However, in all methods lot 6 was considered as having high vigor compared to the others (Table 5).
The temperature of $45^{\circ} \mathrm{C}$ was harmful for the preliminary evaluation of the seeds physiological potential, and it was found that when increasing the seeds exposure time there was no germination. The deleterious effects of rising temperatures associated with stress exposure time were more intense in the traditional accelerated aging, which did not provide the germination of lots from 48 hours, and with saturated solutions these results were observed only within 96 hours of exposure to stress (Table 6).

Table 5. Initial percentages of seed germination $(\mathrm{G})$ and seedling field emergence (E) of niger (Guizotia abyssinica) seeds and after the accelerated aging (AA) periods by the traditional procedures and with saturated salt solution $(\mathrm{NaCl})$ at the temperature of $41^{\circ} \mathrm{C}$.

\begin{tabular}{|c|c|c|c|c|c|c|c|c|c|c|c|c|c|c|}
\hline \multirow{4}{*}{ Lot } & \multirow{3}{*}{ G } & \multirow{3}{*}{ E } & \multirow{2}{*}{\multicolumn{4}{|c|}{ Traditional AA }} & \multicolumn{8}{|c|}{ AA with salt } \\
\hline & & & & & & & \multicolumn{4}{|c|}{$20 \mathrm{~g} \mathrm{NaCl} 100 \mathrm{~mL}^{-1}$} & \multicolumn{4}{|c|}{$40 \mathrm{~g} \mathrm{NaCl} 100 \mathrm{~mL}^{-1}$} \\
\hline & & & $24 \mathrm{~h}$ & $48 \mathrm{~h}$ & $72 \mathrm{~h}$ & $96 \mathrm{~h}$ & $24 \mathrm{~h}$ & $48 \mathrm{~h}$ & $72 \mathrm{~h}$ & $96 \mathrm{~h}$ & $24 \mathrm{~h}$ & $48 \mathrm{~h}$ & $72 \mathrm{~h}$ & $96 \mathrm{~h}$ \\
\hline & \multicolumn{14}{|c|}{$(\%)$} \\
\hline 1 & $86 \mathrm{a}^{1}$ & $33 \mathrm{~b}$ & $28 \mathrm{c}$ & $25 \mathrm{~b}$ & $27 \mathrm{a}$ & $14 \mathrm{bc}$ & $15 \mathrm{c}$ & $20 \mathrm{c}$ & $21 \mathrm{bc}$ & $26 \mathrm{~b}$ & $18 \mathrm{c}$ & $14 \mathrm{c}$ & $17 \mathrm{c}$ & $13 \mathrm{bc}$ \\
\hline 2 & $81 \mathrm{a}$ & $38 \mathrm{~b}$ & $47 \mathrm{~b}$ & $20 \mathrm{~b}$ & $11 \mathrm{~b}$ & $15 \mathrm{~b}$ & $23 \mathrm{bc}$ & $20 \mathrm{c}$ & $17 \mathrm{c}$ & $17 \mathrm{~b}$ & $20 \mathrm{bc}$ & $21 \mathrm{bc}$ & $27 \mathrm{bc}$ & $13 \mathrm{bc}$ \\
\hline 3 & $85 \mathrm{a}$ & $30 \mathrm{~b}$ & $34 \mathrm{bc}$ & $0 \mathrm{c}$ & $29 \mathrm{a}$ & $4 \mathrm{~d}$ & $20 \mathrm{c}$ & $17 \mathrm{c}$ & $25 \mathrm{bc}$ & $15 \mathrm{~b}$ & $14 \mathrm{c}$ & $15 \mathrm{c}$ & $23 \mathrm{c}$ & $20 \mathrm{~b}$ \\
\hline 4 & $84 \mathrm{a}$ & $44 \mathrm{ab}$ & $31 \mathrm{c}$ & $27 \mathrm{~b}$ & $28 \mathrm{a}$ & $6 \mathrm{~cd}$ & $33 \mathrm{~b}$ & $40 \mathrm{~b}$ & $36 \mathrm{~b}$ & $25 \mathrm{~b}$ & $31 \mathrm{~b}$ & $31 \mathrm{~b}$ & $37 \mathrm{~b}$ & $16 \mathrm{bc}$ \\
\hline 5 & $86 \mathrm{a}$ & $41 \mathrm{ab}$ & $23 \mathrm{c}$ & $17 \mathrm{~b}$ & $17 \mathrm{ab}$ & $6 \mathrm{~cd}$ & $20 \mathrm{c}$ & $13 \mathrm{c}$ & $21 \mathrm{bc}$ & $17 \mathrm{~b}$ & $17 \mathrm{c}$ & $15 \mathrm{c}$ & $19 \mathrm{c}$ & $11 \mathrm{c}$ \\
\hline 6 & $91 \mathrm{a}$ & $71 \mathrm{a}$ & $67 \mathrm{a}$ & $46 \mathrm{a}$ & $16 \mathrm{ab}$ & $25 \mathrm{a}$ & $60 \mathrm{a}$ & $66 \mathrm{a}$ & $58 \mathrm{a}$ & $54 \mathrm{a}$ & $72 \mathrm{a}$ & $62 \mathrm{a}$ & $69 \mathrm{a}$ & $79 \mathrm{a}$ \\
\hline C. V. $(\%)$ & 6.1 & 15.2 & 15.9 & 23.9 & 33.3 & 32.6 & 19.9 & 21.3 & 24.3 & 27.9 & 18.5 & 21.5 & 19.3 & 14.2 \\
\hline
\end{tabular}

${ }^{1}$ Means followed by the same letter in the column do not differ among themselves by the Tukey's test at $5 \%$ probability.

Table 6. Initial percentages of seed germination (G) and seedling field emergence (E) of niger (Guizotia abyssinica) seeds and after the accelerated aging (AA) periods by the traditional procedures and with saturated salt solution $(\mathrm{NaCl})$ at the temperature of $45^{\circ} \mathrm{C}$.

\begin{tabular}{|c|c|c|c|c|c|c|c|c|c|c|c|c|c|c|}
\hline \multirow{4}{*}{ Lot } & \multirow{3}{*}{ G } & \multirow{3}{*}{ E } & \multirow{2}{*}{\multicolumn{4}{|c|}{ Traditional AA }} & \multicolumn{8}{|c|}{ AA with salt } \\
\hline & & & & & & & \multicolumn{4}{|c|}{$20 \mathrm{~g} \mathrm{NaCl} 100 \mathrm{~mL}^{-1}$} & \multicolumn{4}{|c|}{$40 \mathrm{~g} \mathrm{NaCl}^{.100 \mathrm{~mL}^{-1}}$} \\
\hline & & & $24 \mathrm{~h}$ & $48 \mathrm{~h}$ & $72 \mathrm{~h}$ & $96 \mathrm{~h}$ & $24 \mathrm{~h}$ & $48 \mathrm{~h}$ & $72 \mathrm{~h}$ & $96 \mathrm{~h}$ & $24 \mathrm{~h}$ & $48 \mathrm{~h}$ & $72 \mathrm{~h}$ & $96 \mathrm{~h}$ \\
\hline & \multicolumn{14}{|c|}{$(\%)$} \\
\hline 1 & $86 \mathrm{a}^{1}$ & $33 \mathrm{~b}$ & $11 \mathrm{~b}$ & 0 & 0 & 0 & $13 \mathrm{c}$ & $14 \mathrm{c}$ & $13 \mathrm{c}$ & 0 & $13 \mathrm{c}$ & $17 \mathrm{bc}$ & $21 \mathrm{~b}$ & 0 \\
\hline 2 & $81 \mathrm{a}$ & $38 \mathrm{~b}$ & $18 \mathrm{~b}$ & 0 & 0 & 0 & $25 \mathrm{bc}$ & $22 \mathrm{bc}$ & $19 \mathrm{bc}$ & 0 & $21 \mathrm{bc}$ & $19 \mathrm{bc}$ & $20 \mathrm{~b}$ & 0 \\
\hline 3 & $85 \mathrm{a}$ & $30 \mathrm{~b}$ & $19 \mathrm{~b}$ & 0 & 0 & 0 & $22 b c$ & $15 \mathrm{bc}$ & $22 \mathrm{bc}$ & 0 & $19 \mathrm{bc}$ & $16 \mathrm{c}$ & $14 \mathrm{~b}$ & 0 \\
\hline 4 & $84 \mathrm{a}$ & $44 \mathrm{ab}$ & $22 \mathrm{~b}$ & 0 & 0 & 0 & $29 \mathrm{~b}$ & $28 \mathrm{~b}$ & $31 \mathrm{~b}$ & 0 & $27 \mathrm{~b}$ & $32 \mathrm{~b}$ & $24 \mathrm{~b}$ & 0 \\
\hline 5 & 86 a & $41 \mathrm{ab}$ & $0 \mathrm{c}$ & 0 & 0 & 0 & $13 \mathrm{c}$ & $10 \mathrm{c}$ & $10 \mathrm{c}$ & 0 & $13 \mathrm{c}$ & $18 \mathrm{bc}$ & $12 \mathrm{~b}$ & 0 \\
\hline 6 & $91 \mathrm{a}$ & $71 \mathrm{a}$ & $64 \mathrm{a}$ & 0 & 0 & 0 & $66 \mathrm{a}$ & $71 \mathrm{a}$ & $65 \mathrm{a}$ & 0 & $64 \mathrm{a}$ & $60 \mathrm{a}$ & $62 \mathrm{a}$ & 0 \\
\hline C. V. (\%) & 6.1 & 15.2 & 35.4 & 0 & 0 & 0 & 25.0 & 23.4 & 23.8 & 0 & 23.3 & 25.4 & 26.2 & 0 \\
\hline
\end{tabular}

${ }^{1}$ Means followed by the same letter in the column do not differ among themselves by the Tukey's test at $5 \%$ probability.

This indicates that from a certain amount of exposure to aging treatment the seeds lose vigor, become more sensitive to stress during germination and subsequently are unable to promote the damages reparation, losing the ability to germinate (Rajjou and Debeaujon, 2008; Samarah and Al-Kofahi, 2008). In studies carried out by Bittencourt and Vieira (2006) and Mendes et al. (2010), maize (Zea mays L.) and castor (Ricinus communis L.) seeds germination reduction was observed after accelerated aging, with increasing temperature decay from 42 to $45^{\circ} \mathrm{C}$, in the first case, and from 41 to $45^{\circ} \mathrm{C}$, in the second one. The test completion on Jatropha curcas (common names include Barbados nut, purging nut, physic nut, or JCL (abbreviation of Jatropha curcas Linnaeus)) seeds by Pereira et al. (2012) has provided layering of the lots only at the temperature of $41^{\circ} \mathrm{C}$, 
being considered limiting the temperatures of 42 and $45{ }^{\circ} \mathrm{C}$, while for wheat (Triticum aestivum L.) seeds the temperature of $45^{\circ} \mathrm{C}$ was lethal (Maia et al., 2007).

Similar results were obtained by Lehner et al. (2008), where wheat (Triticum aestivum L.) seeds showed less sensitivity to accelerated aging in an environment with a relative humidity of $75 \%$ compared to the environment with $100 \%$ humidity. Probably, the test period was increased in the modified procedure due to the lesser degree of decay experienced by the seeds. Thus, the use of a saturated solution became important in controlling the aging chamber relative humidity, reducing the seeds decay, the variation between the samples water content and the infestation by microorganisms.

There was a significant correlation between the seedlings emergence and accelerated aging tests conducted for 24 hours by the traditional method at $41{ }^{\circ} \mathrm{C}$. There was no correlation $(\mathrm{r}=0)$ with tests conducted at $45{ }^{\circ} \mathrm{C}$ for 96 hours in the two salt concentrations, and after 48 hours in the conventional method (Table 7). The other methods were significantly correlated $(\mathrm{p}<0.05)$ with seedling emergence, indicating that they are able to estimate this test, observing low and negative correlation only in the test conducted by the traditional method for 72 hours (Table 7).

However, given that the results accuracy was hampered by the samples water content variation, the traditional accelerated aging test was not recommended for the evaluation of the niger seeds physiological quality, even when it allowed the lots stratification in levels of vigor or correlated with the seedling emergence test, and testing conducted with a saturated salt solution can be used as an alternative.

Table 7. Simple Pearson correlation coefficients (r) estimated between accelerated aging tests (AA) and seedling field emergence in six lots of niger (Guizotia abyssinica) seeds.

\begin{tabular}{|c|c|c|c|c|c|c|c|c|c|c|c|c|}
\hline & \multirow{2}{*}{\multicolumn{4}{|c|}{ Traditional AA }} & \multicolumn{8}{|c|}{ AA with salt } \\
\hline & & & & & \multicolumn{4}{|c|}{$20 \mathrm{~g} \mathrm{NaCl} 100 \mathrm{~mL}^{-1}$} & \multicolumn{4}{|c|}{$40 \mathrm{~g} \mathrm{NaCl} 100 \mathrm{~mL}^{-1}$} \\
\hline & $24 \mathrm{~h}$ & $48 \mathrm{~h}$ & $72 \mathrm{~h}$ & $96 \mathrm{~h}$ & $24 \mathrm{~h}$ & $48 \mathrm{~h}$ & $72 \mathrm{~h}$ & $96 \mathrm{~h}$ & $24 \mathrm{~h}$ & $48 \mathrm{~h}$ & $72 \mathrm{~h}$ & $96 \mathrm{~h}$ \\
\hline $41^{\circ} \mathrm{C}$ & $0.791^{\mathrm{ns}}$ & $0.865^{* *}$ & $-0.426^{*}$ & $0.748^{* *}$ & $0.966^{* *}$ & $0.919^{*}$ & $0.911^{* *}$ & $0.920^{* *}$ & $0.975^{* *}$ & $0.966^{* *}$ & $0.949^{* *}$ & $0.912^{* *}$ \\
\hline $45^{\circ} \mathrm{C}$ & $0.863^{* *}$ & 0.000 & 0.000 & 0.000 & $0.923^{* *}$ & $0.947^{*}$ & $0.908^{* *}$ & 0.000 & $0.943^{* *}$ & $0.972^{* *}$ & $0.936^{* *}$ & 0.000 \\
\hline
\end{tabular}

(*) Significant at $5 \%$ probability by the t-test; $(* *)$ Significant at $1 \%$ probability by the t-test; (ns) nonsignificant at $5 \%$ probability by the t-test and (AA) accelerated aging.

Among the studies on oil varieties, Braga Junior et al. (2011) have considered that the accelerated aging test modified with a saturated solution of $40 \mathrm{~g} \mathrm{NaCl} .100 \mathrm{~mL}^{-1}$ at $40{ }^{\circ} \mathrm{C}$ for 48 hours was the most appropriate method for classification of lots of castor (Ricinus communis L.) seeds. On the other hand, Nery et al. (2009) have found that the accelerated aging test at $41{ }^{\circ} \mathrm{C}$ for 96 hours and with saturated solution of $\mathrm{NaCl}$ at $41{ }^{\circ} \mathrm{C}$ for 72 hours is effective in evaluating the physiological potential of forage turnip (Raphanus sativus L.) seeds. As for Amaro et al. (2014) and Lima et al. (2015), the accelerated aging test under the condition of $41{ }^{\circ} \mathrm{C}$ for 72 hours provides greater differentiation of vigor among lots of crambe abyssinica (Crambe abyssinica Hochst) seeds.

Thus, it appears that the methods used to conduct the test vary with the genotype observing difference in the behavior of seeds with the temperatures and times of exposure to the accelerated aging test as well as the use and the concentration of the saline solution in the same way that the rate of decay of seeds varies among species and among lots of seeds of the same species (Kibinza et al., 2011).

\section{Conclusions}

The accelerated aging test is efficient to evaluate the physiological potential of niger seeds, and the method with $20 \mathrm{~g} \mathrm{NaCl} .100 \mathrm{~mL}^{-1}$ is recommended at $41{ }^{\circ} \mathrm{C}$ for 24 hours.

The traditional method is not suitable due to providing variation of water content between the samples, exceeding what is tolerable.

\section{References}

AMARO, H.T.R.; DAVID, A.M.S.S.; SILVA NETA, I.C.; ASSIS, M.O.; ARAÚJO, E.F.; ARAÚJO, R.F. Teste de envelhecimento acelerado em sementes de crambe (Crambe abyssinica Hochst), cultivar FMS Brilhante. Revista Ceres, v.61, n.2, p.202-208, 2014. http://www.scielo.br/scielo. php?pid=S0034-737X2014000200007\&script=sci_arttext

BITTENCOURT, S. R. M.; VIEIRA, R.D. Temperatura e período de exposição de sementes de milho no teste envelhecimento acelerado. Revista Brasileira de Sementes, v.28, n.3, p.161-168, 2006. http://www.scielo.br/pdf/ $\mathrm{rbs} / \mathrm{v} 28 \mathrm{n} 3 / 23 . \mathrm{pdf}$

BOLEK, Y. Genetic variability among cotton genotypes for cold tolerance. Field Crops Research, v.119, n.1, p.59-67, 2010. http://www.sciencedirect. com/science/article/pii/S0378429010001620 
BRAGA JUNIOR, J.M.; ROCHA, M.S.; BRUNO, R.L.A.; VIANA, J.S.; BELTRÃO, N.E.M. Teste de envelhecimento acelerado em sementes de mamona cultivar BRS -Energia. Revista Eletrônica de Biologia, v.4, n.1, p.88101, 2011. http://revistas.pucsp.br/index.php/reb/article/view/2764/5847

BRASIL. Ministério da Agricultura, Pecuária e Abastecimento. Regras para análise de sementes. Ministério da Agricultura, Pecuária e Abastecimento. Secretaria de Defesa Agropecuária. Brasília: MAPA/ACS, 2009. 395p. http:// www.agricultura.gov.br/arq_editor/file/2946_regras_analise_sementes.pdf

BRAZ, M.R.S.; BARROS, C.S.; CASTRO, F.P.; ROSSETTO, C.A.V. Testes de envelhecimento acelerado e deterioração controlada na avaliação do vigor de aquênios de girassol. Ciência Rural, v.38, n.7, p.1857-1863, 2008. http:// www.scielo.br/pdf/cr/v38n7/a09v38n7.pdf

CARNEIRO, M.A.C.; CORDEIRO, M.A.S.; ASSIS, P.C.R.; MORAES, E.S.; PEREIRA, H.S.; PAULINO, H.B.; SOUZA, E.D. Produção de fitomassa de diferentes espécies de cobertura e suas alterações na atividade microbiana de solo de cerrado. Bragantia, v.67, n.2, p.455-462, 2008. http://www.scielo.br/ pdf/brag/v67n2/a21v67n2.pdf

CASTRO, R.D.; BRADFORD, K.J.; HILHORST, H.W.M. Embebição e reativação do metabolismo. In: Ferreira, A.G.; Borghetti, F. (Eds.) Germinação: do básico ao aplicado. Porto Alegre, Artmed, 2004. p.149-162.

EDMOND, J.B.; DRAPALLA, W.J. The effects of temperature, sand and soil, and acetone on germination on okra seeds. Proceedings of the American Society Horticultural Science, v.71, p.428-34, 1958.

FERREIRA, D.F. Sisvar: a computer statistical analysis system. Ciência e Agrotecnologia, v.35, n.6, p.1039-1042, 2011. http://www.scielo.br/pdf/ cagro/v35n6/a01v35n6.pdf

GETINET, A.; SHARMA, S.M. Niger (Guizotia abyssinica (L. f.) Cass. Promoting the conservation and use of underutilized and neglected crops 5. Institute of Plant Genetics and Crop Plant Research, Gatersleben/ International Plant Genetic Resources Institute, Rome, 1996. 59 p.

GORDIN, C.R.B.; MARQUES, R.F.M.; MASETTO, T.E.; SCALON, S.P.Q. Germinação, biometria de sementes e morfologia de plântulas de Guizotia abyssinica Cass. Revista Brasileira de Sementes, v.34, n.4, p.619-627, 2012. http://www.scielo.br/scielo.php?script=sci_ arttext\&pid=S0101-31222012000400013

GREY, T.; BEASLEY JUNIOR, J.P.; WEBSTER, T.M.; CHEN, C.Y. Peanut seed vigor evaluation using a thermal gradient. International Journal of Agronomy, v.2011, p.1-7, 2011. http://www.hindawi.com/journals/ija/2011/202341/

JIANHUA, Z.; McDONALD, M.B. The saturated salt accelerated aging test for small-seeded crops. Seed Science and Technology, v.25, p.123-131, 1996. http://agris.fao.org/agris-search/search.do?recordID=CH9700211

KIBINZA, S.; BAZIN, J.; BAILLY, C.; FARRANT, J.M.; CORBINEAU, F.; EL-MAAROUF-BOUTEAU, H. Catalase is a key enzyme in seed recovery from aging during priming. Plant Science, v.181, p.309-315, 2011. http:// www.sciencedirect.com/science/article/pii/S016894521100166X

KUO, W.L.; CHEN, C.C.; CHANG, P.H.; CHENG, L.Y.; SHIEN, B.J.; HUANG, Y.L. Flavonoids from Guizotia abyssinica. Journal of Chinese Medicine, v.18, n.3, p.121-128, 2007. http://ejournal.nricm.edu.tw/ upload/21614/18/1803-03.pdf

LEHNER, A.; MAMADOU, N.; PELS, P.; CÔME, D.; BAILlY, C.; CORBINEAU, F. Changes in soluble carbohydrates, lipid peroxidation and antioxidant enzyme activities in the embryo during aging in wheat grains. Journal of Cereal Science, v.47, p.555-565, 2008. http://www.sciencedirect. com/science/article/pii/S0733521007001312
LIMA, J.J.P.; FREITAS, M.N.; GUIMARÃES, R.M.; VIEIRA, A.R.; ÁVILA, M.A.B. Accelerated aging and electrical conductivity tests in crambe seeds. Ciência e Agrotecnologia, v.39, n.1, p.7-14, 2015. http://www. scielo.br/scielo.php?pid=S1413-70542015000100007\&script=sci arttext

MAGUIRE, J.B. Speed of germination-aid in selection and evaluation for seedling emergence vigor. Crop Science, v.2, n.2, p.176-177, 1962.

MAIA, A.R.; LOPES, J.C.; TEIXEIRA, C.O. Efeito do envelhecimento acelerado na avaliação da qualidade fisiológica de sementes de trigo. Ciência e Agrotecnologia, v.31, n.3, p.678-684, 2007. http://www.scielo.br/scielo. php?pid=S1413-70542007000300012\&script=sci_arttext

MARCOS-FILHO, J. Fisiologia de sementes de plantas cultivadas. Piracicaba: FEALQ, 2005.495p.

MENDES, R.C.; DIAS, D.C.F.S.; PEREIRA, M.D.; DIAS, L.A.S. Testes de vigor para a avaliação do potencial fisiológico de sementes de mamona (Ricinus communis L.). Ciência e Agrotecnologia, v.34, n.1, p.114-120, 2010. http://www.scielo.br/pdf/cagro/v34n1/15.pdf

MONCALEANO-ESCANDON， J.; SILVA， B.C.F.; SILVA， S.R.S.; GRANJA, J.A.A.; ALVES, M.C.J.L.; POMPELLI, M.F. Germination responses of Jatropha curcas L. seeds to storage and aging. Industrial Crops and Products, v.44, p.684-690, 2013. http://www.sciencedirect.com/science/ article/pii/S0926669012005092

NERY, M.C.; CARVALHO, M.L.M.; GUIMARÃES, R.M. Testes de vigor para avaliação da qualidade de sementes de nabo forrageiro. Informativo Abrates, v.19, n.1, 2009. http://www.abrates.org.br/images/stories/ informativos/v19n1/artigo04.pdf

PENG, Q.; KONG, Z.; LIAO, X.; LIU, Y. Effects of accelerated aging on physiological and biochemical characteristics of waxy and non-waxy wheat seeds. Journal of Northeast Agricultural University, v.18, n.2, p.7-12, 2011. http://www.sciencedirect.com/science/article/pii/S1006810412600026

PEREIRA, M.D., MARTINS FILHO, S.; LAVIOLA, B.G. Envelhecimento acelerado de sementes de pinhão-manso. Pesquisa Agropecuária Tropical, v.42, n.1, p.119-123, 2012. http://www.scielo.br/pdf/pat/v42n1/17.pdf

RAJJOU, L.; DEBEAUJON, I. Seed longevity: Survival and maintenance of high germination ability of dry seeds. Comptes Rendus Biologies, v.331, p.796-805, 2008. http://www.sciencedirect.com/science/article/pii/ S1631069108002011\#

SAMARAH, N.H.; AL-KOFAHI, S. Relationship of seed quality tests to field emergence of artificial aged barley seeds in the Semiarid Mediterranean region. Jordan Journal of Agricultural Sciences, v.4, n.3, p.217-230, 2008. https://journals.ju.edu.jo/JJAS/article/viewFile/1001/994

SARIN, R.; SHARMA, M.; KHAN, A.A. Studies on Guizotia abyssinica L. oil: Biodiesel synthesis and process optimization. Bioresource Technology, v.100, p.4187-4192, 2009. http://www.ncbi.nlm.nih.gov/pubmed/19386491

SOLOMON, W.K.; ZEWDU, A.D. Moisture-dependent physical properties of niger (Guizotia abyssinica Cass.) seed. Industrial crops and products, v.29, p.165-170, 2009. http://www.researchgate.net/publication/238363949_ Moisturedependent_physical_properties_of_niger_\%28_Guizotia abyssinica_Cass.\%29_seed

VENTURA, L.; DONÀ, M.; MACOVEI, A.; CARBONERA, D.; BUTTAFAVA, A.; MONDONI, A.; ROSSI, G.; BALESTRAZZI, A. Understanding the molecular pathways associated with seed vigor. Plant Physiology and Biochemistry, v.60, p.196-206, 2012. http://www.ncbi.nlm. nih.gov/pubmed/22995217 